Jurnal Kependudukan Indonesia | Vol. 14 No. 2 Desember 2019| 119-136

JURNAL KEPENDUDUKAN INDONESIA

p-ISSN : 1907-2902 (Print)

e-ISSN : 2502-8537 (Online)

\title{
PENANGANAN UNMET NEED KB DI KAMPUNG KB: STUDI KASUS DI DUA KAMPUNG KB DI KABUPATEN CIANJUR
}

\section{(HANDLING UNMET NEED FOR FAMILY PLANNING IN KAMPUNG KB: A CASE STUDY IN TWO KAMPUNG KB IN CIANJUR REGENCY)}

\author{
Sri Sulastri ${ }^{1}$, Hetty Krisnani ${ }^{1}$, Diah Puspita Sari ${ }^{2}$, Rindang Ekawati ${ }^{3}$ \\ ${ }^{1}$ Pusat Studi CSR, Kewirausahaan Sosial, dan Pengembangan Masyarakat \\ FISIP Universitas Padjadjaran; \\ ${ }^{2}$ Pusat Penelitian dan Pengembangan KB dan KS BKKBN \\ ${ }^{3}$ Pusat Pelatihan dan Pengembangan Perwakilan BKKBN Provinsi Jawa Barat \\ *Korespondensi: sri.sulastri@unpad.ac.id
}

\begin{abstract}
One of the tasks of Kampung KB (Keluarga Berencana) is to reduce the proportion of unmet need for family planning by utilizing family planning field officers and gaining support from related institutions. This study aims to analyze the process of handling the unmet need for family planning in two Kampung KB in Cianjur Regency. The research used a qualitative approach in forms of individual in-depth interviews and focus group discussions. Data are analyzed descriptively based on case studies. The findings indicate that data recording instruments used daily in the research sites have not been able to identify groups of women with unmet need for family planning. Therefore, the existing services of family planning information have not been based on the needs of the target group. After the formation of Kampung KB, family planning information services and contraception services were more vigorous. While all of the services ease couples of childbearing age with unmet need for family planning to get related information and contraception, monitoring and evaluation activities still cannot be carried out because of the unavailability of officers as well as the target group and post-service data. In addition, there is no clear division of labor between the board Kampung KB and other family planning field officers in each stage of the handling of unmet need for family planning.
\end{abstract}

Keywords: unmet need for family planning, kampung $\mathrm{KB}$, reproductive health, community capacity building

\begin{abstract}
Abstrak
Salah satu tugas Kampung KB (Keluarga Berencana) adalah menurunkan proporsi unmet need $\mathrm{KB}$ dengan mendayagunakan para petugas lapangan $\mathrm{KB}$ dan menggalang dukungan dari institusi terkait. Tujuan penelitian ini adalah untuk menganalisis proses penanganan unmet need $\mathrm{KB}$ di dua Kampung KB di Kabupaten Cianjur. Metode penelitian yang digunakan adalah pendekatan kualitatif melalui wawancara mendalam dan diskusi kelompok terfokus. Data dianalisis secara deskriptif berdasarkan studi kasus. Hasil penelitian menunjukkan bahwa instrumen pencatatan data yang digunakan sehari-hari di lokasi penelitian belum dapat mengidentifikasi kelompok wanita dengan unmet need KB. Situasi ini menyebabkan pelayanan informasi KB yang ada belum didasarkan atas kebutuhan kelompok sasaran. Setelah pembentukan Kampung KB, layanan informasi KB dan layanan kontrasepsi lebih gencar dilakukan. Meskipun semua layanan ini memudahkan pasangan usia subur dengan unmet need $\mathrm{KB}$ untuk mendapatkan informasi terkait dan kontrasepsi, kegiatan monitoring dan evaluasi belum dapat dilakukan karena ketiadaan petugas, serta data kelompok sasaran dan data pasca layanan tidak tersedia. Selain itu, belum ada pembagian kerja yang jelas antara pengurus Kampung KB dan petugas lapangan $\mathrm{KB}$ lainnya dalam setiap tahap kegiatan penanganan unmet need $\mathrm{KB}$.
\end{abstract}

Kata kunci: unmet need $\mathrm{KB}$, kampung $\mathrm{KB}$, kesehatan reproduksi, pengembangan kapasitas komunitas. 


\section{PENDAHULUAN}

Konsep unmet need for family planning atau unmet need keluarga berencana $(\mathrm{KB})$ atau kebutuhan $\mathrm{KB}$ yang tidak terpenuhi merujuk pada wanita subur (fecund) berusia 15-49 tahun berstatus menikah yang ingin menunda kehamilan atau ingin membatasi kelahiran (tidak ingin punya anak lagi) tetapi tidak menggunakan alat/metode kontrasepsi. Selain itu, wanita yang sedang hamil atau baru saja melahirkan, apabila kehamilan atau kelahiran anak tersebut tidak diinginkan pada saat itu atau sebenarnya tidak ingin memiliki anak lagi, maka ia juga termasuk dalam kategori unmet need $\mathrm{KB}$ atau kebutuhan alat kontrasepsinya tidak terpenuhi (Bradley dkk., 2012).

Penggunaan alat/metode kontrasepsi merupakan salah satu upaya pengendalian kehamilan yang tidak hanya diperlukan untuk pengendalian jumlah penduduk, tetapi juga untuk kesehatan reproduksi wanita Pasangan Usia Subur (PUS) dan kesehatan janin atau bayinya. Untuk kesehatan reproduksi wanita PUS dan bayinya, penggunaan alat/metode kontrasepsi ditujukan untuk menghindari risiko kehamilan, terutama bagi wanita PUS yang berada dalam kelompok empat "terlalu", yaitu terlalu muda (kehamilan di usia kurang dari 20 tahun), terlalu rapat atau dekat (jarak kehamilan kurang dari dua tahun), terlalu banyak (hamil lebih dari empat kali), dan terlalu tua (kehamilan di usia di atas 35 tahun). Jika hamil, wanita PUS yang termasuk dalam empat kategori ini menghadapi risiko yang tinggi karena kondisi rahim yang belum siap, belum pulih, atau jika terjadi kekendoran dapat menyebabkan kehamilan dan persalinan bermasalah. Hal ini dapat mengakibatkan rendahnya kondisi kesehatan ibu dan bayinya, bahkan dapat menyebabkan kematian (Warung Bidan, 2016). Oleh karena itu, tingkat kesertaan aktif $\mathrm{KB}$ (contraceptive prevalence rate atau $C P R$ ) dan tingkat unmet need $\mathrm{KB}$ merupakan dua di antara enam indikator kesehatan ibu.

Penanganan unmet need $\mathrm{KB}$ merupakan salah satu Program Kependudukan, Keluarga Berencana dan Pembangunan Keluarga (KKBPK) BKKBN. Pada tahun 2015-2019, penurunan unmet need $\mathrm{KB}$ masih merupakan salah satu sasaran strategis BKKBN. Dengan mengacu pada capaian tahun 2012 yaitu $11,14 \%$, target lima tahun berikutnya sedikit demi sedikit diturunkan, mulai dari tahun 2015 (10,60\%), 2016 (10,48\%), 2017 (10,26\%), 2018 (10,14\%), dan tahun $2019(9,91 \%)$ (BKKBN, 2016). Namun demikian, berdasarkan data hasil Survei Kinerja dan Akuntabilitas Program (SKAP) KKBPK tahun 2017, tingkat unmet need $\mathrm{KB}$ nasional masih sebesar $12,6 \%$, yang terdiri atas $3,8 \%$ unmet need $\mathrm{KB}$ untuk menunda kehamilan dan $8,8 \%$ untuk membatasi kehamilan (Puslitbang KB dan KS BKKBN, 2017). Sementara itu, data SDKI tahun 2017 masih menunjukkan angka unmet need sebesar 10,6\% (BPS, BKKBN, \& Macro Inc. 2017). Selanjutnya, data tahun 2019 mengungkapkan bahwa kebutuhan KB yang tidak terpenuhi di Indonesia masih sekitar 10,6\% (Humas BKKBN, 2019). Data unmet need KB tersebut masih lebih tinggi dari target capaian tahun 2017 (10,26\%).

Capaian tingkat unmet need $\mathrm{KB}$ yang masih lebih tinggi dari target yang diharapkan dipengaruhi oleh adanya wilayah dengan tingkat kesertaan PUS ber-KB relatif rendah. Untuk itu, BKKBN mengembangkan strategi yang dapat memperkuat upaya pencapaian target/sasaran Pembangunan Bidang KKBPK 20152019 dengan cara membentuk Kampung KB di wilayah setingkat RW atau dusun, yang salah satu kriterianya adalah tingkat kesertaan PUS ber-KB masih relatif rendah dan tingkat unmet need $\mathrm{KB}$ lebih tinggi dari capaian rata-rata tingkat desa.

Pembentukan Kampung KB mulai dicanangkan pada tahun 2016. Kampung KB dikelola oleh pengurus yang berasal dari warga RW atau dusun setempat dan kepala desa/lurah setempat sebagai pelindung/penanggung jawab. Mereka bertugas melakukan identifikasi masalah dan potensi (assessment), serta merencanakan, melaksanakan, dan mengevaluasi kegiatan. Pengurus Kampung KB dalam melaksanakan tugasnya didampingi oleh penyuluh $\mathrm{KB}$ atau petugas lapangan $\mathrm{KB}(\mathrm{PKB} / \mathrm{PLKB})$ dan petugas lini lapangan lainnya yang memberikan fasilitasi terutama dalam proses pengumpulan, pengolahan, dan analisis data untuk identifikasi masalah dan potensi wilayah. Selain itu, PKB/PLKB melakukan advokasi kepada pemerintah desa dan sektor terkait (BKKBN, 2017).

Keberadaan Kampung KB sebagai strategi baru dalam penanganan unmet need $\mathrm{KB}$ menarik dan penting untuk diteliti. Pertanyaan penelitian yang ingin dijawab melalui penelitian ini adalah bagaimana keseluruhan proses penanganan unmet need KB di Kampung KB. Terkait dengan pertanyaan penelitian tersebut, tujuan penelitian ini adalah untuk mendeskripsikan dan 
menganalisis (i) proses assessment untuk identifikasi jumlah PUS unmet need KB, karakteristik demografis, dan alasan tidak menggunakan alat/metoda kontrasepsi; (ii) proses perencanaan kegiatan KIE (komunikasi, informasi, edukasi)/konseling $\mathrm{KB}$; (iii) proses pelaksanaan KIE/konseling $\mathrm{KB}$ dan pelayanan kontrasepsi; dan (iv) proses monitoring dan evaluasi.

Penanganan unmet need KB tidak hanya memerlukan pengukuran besaran angkanya, tetapi juga pemahaman mengenai faktor-faktor penyebabnya. Pengetahuan terkait kedua hal ini penting untuk menentukan upaya intervensi yang tepat sesuai dengan permasalahan yang ada. Machiyama dkk. (2017:4) mengemukakan bahwa faktor-faktor yang menyebabkan unmet need $\mathrm{KB}$ (2017:4) meliputi (i) keinginan wanita PUS yang lemah atau tidak konsisten atau ambivalen untuk menunda atau mengakhiri kehamilan; (ii) berbagai hambatan sosial, budaya, psikologis, dan ekonomi; (iii) persepsi wanita tentang hal-hal yang terkait dengan metode kontrasepsi tertentu, terutama tentang efek samping yang dialami dirinya atau teman-temannya; (iv) wanita tidak merasa dirinya berisiko hamil karena merasa tidak subur secara permanen atau karena faktor-faktor yang tidak permanen seperti amenore laktasi, pantangan seksual, dan frekuensi koitus rendah; dan (v) faktorfaktor terkait dengan pasangan (suami) yang dapat memengaruhi keputusan isteri untuk tidak menggunakan kotrasepsi. Faktor-faktor ini selaras dengan alasan PUS tidak menggunakan alat/metode kontrasepsi pada SDKI. Alasan-alasan ini berkaitan dengan karakteristik demografis mereka, seperti umur, pendidikan, pekerjaan, dan jumlah anak yang hidup (Ali \& Okud, 2013; Hameed dkk., 2011; Pal dkk., 2014). Wanita PUS unmet need $\mathrm{KB}$, baik yang pernah maupun belum pernah menggunakan alat kontrasepsi memberikan sumbangan yang cukup besar pada jumlah unmet need KB (Jain dkk., 2013).

Faktor penyebab unmet need KB berkaitan dengan pelayanan informasi tentang alat atau metode kontrasepsi. Bruce (1990:64) telah mengembangkan kerangka teoritis pengaruh dimensi kualitas pelayanan terhadap pengetahuan, kepuasan, kesehatan wanita PUS sehingga mereka mau menerima salah satu alat/metode kontrasepsi tertentu dan menggunakannya secara berkelanjutan. Kualitas layanan keluarga berencana dapat dinilai berdasarkan enam dimensi kunci yaitu (i) pilihan metode kontrasepsi yang ditawarkan; (ii) informasi yang diberikan kepada klien; (iii) kompetensi teknis penyedia layanan; (iv) hubungan interpersonal antara penyedia layanan dan klien; (v) tindak lanjut dan kontinuitas layanan; dan (vi) konstelasi layanan yang ditawarkan. Layanan berkualitas baik tidak hanya menarik klien baru tetapi juga dapat membantu mencegah penghentian penggunaan kontrasepsi.

Untuk mendukung kualitas layanan tersebut diperlukan proses sistematis berbasis fakta, meliputi kegiatan assessment untuk menentukan siapa dan dimana sasaran layanan, serta faktor penyebab unmet need KB. Para perencana menentukan intervensi yang layak, dapat diterima, efektif, dan berkelanjutan, dengan memperhatikan kondisi lokal dan sumber daya yang tersedia; dalam pelaksanaannya diperlukan kolaborasi efektif dari stakeholders terkait. Kemitraan semacam itu perlu dibangun untuk mendukung proses pelayanan yang diperlukan dan agar dapat dijangkau oleh semua orang (PATH UNFPA, 2008).

\section{METODE PENELITIAN}

Merujuk pada tujuan penelitian, penelitian ini menggunakan pendekatan kualitatif. Data primer dikumpulkan melalui wawancara mendalam terhadap beberapa informan yang relevan dan diskusi kelompok terfokus. Data sekunder menggunakan dokumen dokumen dan data yang dikumpulkan oleh pengelola program. Selain itu, kajian ini merupakan kajian deskriptif yang memungkinkan penelusuran proses penanganan unmet need $\mathrm{KB}$ dengan banyak variabel yang saling berhubungan secara rinci. Terkait dengan pertanyaan penelitian yang berfokus pada peristiwaperistiwa kontemporer dari sebuah upaya intervensi yang telah dilakukan dengan keadaan kehidupan nyata yang diakibatkannya, maka strategi penelitian yang relevan adalah studi kasus. Desain studi kasus yang relevan dengan objek penelitian ini adalah embedded case study design, yaitu desain studi kasus untuk mempelajari kasus yang memiliki lebih dari satu subunit analisis (Yin, 2003).

Penelitian ini dilakukan di dua Kampung KB di Kabupaten Cianjur. Lokasi pertama adalah Kampung KB RW 04 Desa Mulyasari Kecamatan Cilaku, di sini terdapat 133 PUS unmet need KB dari 377 PUS; menduduki peringkat kedua di antara 33 Kampung KB yang ada di Kabupaten Cianjur. Lokasi kedua, 
Kampung KB RW 05 Desa Kertasari Kecamatan Haurwangi, dipilih sebagai lokasi penelitian karena memiliki jumlah PUS unmet need KB relatif sedikit (13 PUS dari 144 PUS). Data jumlah kasus PUS unmet need $\mathrm{KB}$ ini berdasarkan hasil pendataan keluarga tahun 2015 sebelum Kampung KB terbentuk. Perbedaan proporsi jumlah kasus PUS unmet need $\mathrm{KB}$ di kedua Kampung KB ini kemungkinan berkaitan dengan kondisi dan implementasi program sebelumnya.

Saat penelitian ini dilakukan di kedua Kampung KB ini, terdapat penyuluh $\mathrm{KB}$ /petugas lapangan $\mathrm{KB}$ ( $\mathrm{PKB}$ / PLKB). Pada kenyataannya, tidak semua desa di Kabupaten Cianjur memiliki staf PKB/PLKB. Hal ini dikarenakan ketersediaan jumlah staf yang terbatas. PKB/PLKB adalah PNS pejabat fungsional yang memenuhi kualifikasi dan standar kompetensi serta diberi tugas, tanggung jawab, wewenang dan hak secara penuh oleh pejabat yang berwenang untuk melaksanakan kegiatan penyuluhan, pelayanan, penggerakan dan pengembangan program KKBPK (Permenpan No. 21 tahun 2018). PLKB/PKB saat ini berstatus sebagai pegawai BKKBN Pusat yang ditempatkan di tingkat desa. Di dalam pengelolaan Kampung KB, PKB/PLKB memiliki peran penting sebagai fasilitator bagi Pengurus Kampung KB dalam melaksanakan tugasnya (BKKBN, 2017:14).

Cakupan data, informan, dan teknik pengumpulan data yang digunakan dalam kajian ini tersaji pada Tabel 1 . Selanjutnya, sub-unit analisis dalam penelitian ini adalah institusi pengelola program, institusi/lembaga yang menjadi mitra kerjanya, dan kelompok sasaran pelayanan yaitu PUS unmet need KB.

Analisis terkait dengan proses layanan, kualitas layanan, faktor penyebab unmet need $\mathrm{KB}$, dan Kampung KB di dasarkan pada kerangka konseptual penelitian penanganan unmet need $\mathrm{KB}$ di Kampung KB (Gambar 1). Kerangka konseptual ini juga menjadi rujukan dalam proses pengumpulan dan analisis data.

Tabel 1. Cakupan data, informan, dan teknik pengumpulan data

\begin{tabular}{|c|c|c|c|}
\hline Data & Kategori Informan & $\begin{array}{l}\text { Jumlah } \\
\text { (Orang) }\end{array}$ & $\begin{array}{c}\text { Teknik Pengumpulan } \\
\text { data }\end{array}$ \\
\hline $\begin{array}{l}\text { - Proses assessment } \\
\text { - Proses perencanaan } \\
\text { Pelayanan KIE/ } \\
\text { Konseling KB } \\
\text { - Proses Pelayanan } \\
\text { KIE/Konseling KB } \\
\text { - Proses Pelayanan } \\
\text { Alat Kontrasepsi }\end{array}$ & $\begin{array}{l}\text { - Sub PPKBD } \\
\text { - Kader Posyandu } \\
\text { - Pengurus Kampung KB } \\
\text { - RT } \\
\text { - RW } \\
\text { - PKB/PLKB } \\
\text { - Bidan Desa } \\
\text { - PPL Posyandu } \\
\text { - PPKBD }\end{array}$ & $\begin{array}{l}1 \\
16 \\
16 \\
4 \\
2 \\
1 \\
2 \\
2 \\
3\end{array}$ & $\begin{array}{l}\text { Data Primer: } \\
\text { Wawancara secara } \\
\text { berkelompok dan } \\
\text { individual } \\
\text { Data Sekunder: } \\
\text { Data yang dikumpulkan } \\
\text { oleh pengelola program } \\
\text { atau dokumen terkait. }\end{array}$ \\
\hline $\begin{array}{l}\text { - Proses Monitoring } \\
\text { dan Evaluasi }\end{array}$ & $\begin{array}{l}\text { - PKB/PLKB } \\
\text { - Kepala Korwil PPKBP3A Kecamatan } \\
\text { - Staf Korwil PPKBP3A Kecamatan }\end{array}$ & $\begin{array}{l}1 \\
2 \\
2\end{array}$ & $\begin{array}{l}\text { Data Primer: } \\
\text { Wawancara } \\
\text { Data Sekunder: } \\
\text { Dokumen terkait }\end{array}$ \\
\hline $\begin{array}{l}\text { Tanggapan PUS } \\
\text { unmet need } \mathrm{KB} \text { atas } \\
\text { pelayanan yang } \\
\text { diterima. }\end{array}$ & - PUS unmet need KB penerima layanan & 9 & $\begin{array}{l}\text { Data Primer: } \\
\text { Wawancara } \\
\text { Data Sekunder: } \\
\text { Dokumen terkait }\end{array}$ \\
\hline $\begin{array}{l}\text { Dukungan dari } \\
\text { Pemerintah Desa, } \\
\text { Kecamatan, dan } \\
\text { Kabupaten Kota }\end{array}$ & $\begin{array}{l}\text { - Kepala Desa } \\
\text { - Kepala Korwil PPKBP3A Kecamatan } \\
\text { - Staf Korwil PPKBP3A Kecamatan } \\
\text { - Ka. Bid. Dalduk dan KB DPPKBP3A } \\
\text { Kabupaten Cianjur } \\
\text { - Seksi Dalduk dan Informasi Keluarga }\end{array}$ & $\begin{array}{l}2 \\
2 \\
2 \\
1 \\
1 \\
1\end{array}$ & $\begin{array}{l}\text { Data Primer: } \\
\text { Wawancara } \\
\text { Data Sekunder: } \\
\text { Dokumen terkait }\end{array}$ \\
\hline
\end{tabular}


Gambar 1. Kerangka Konseptual Penelitian

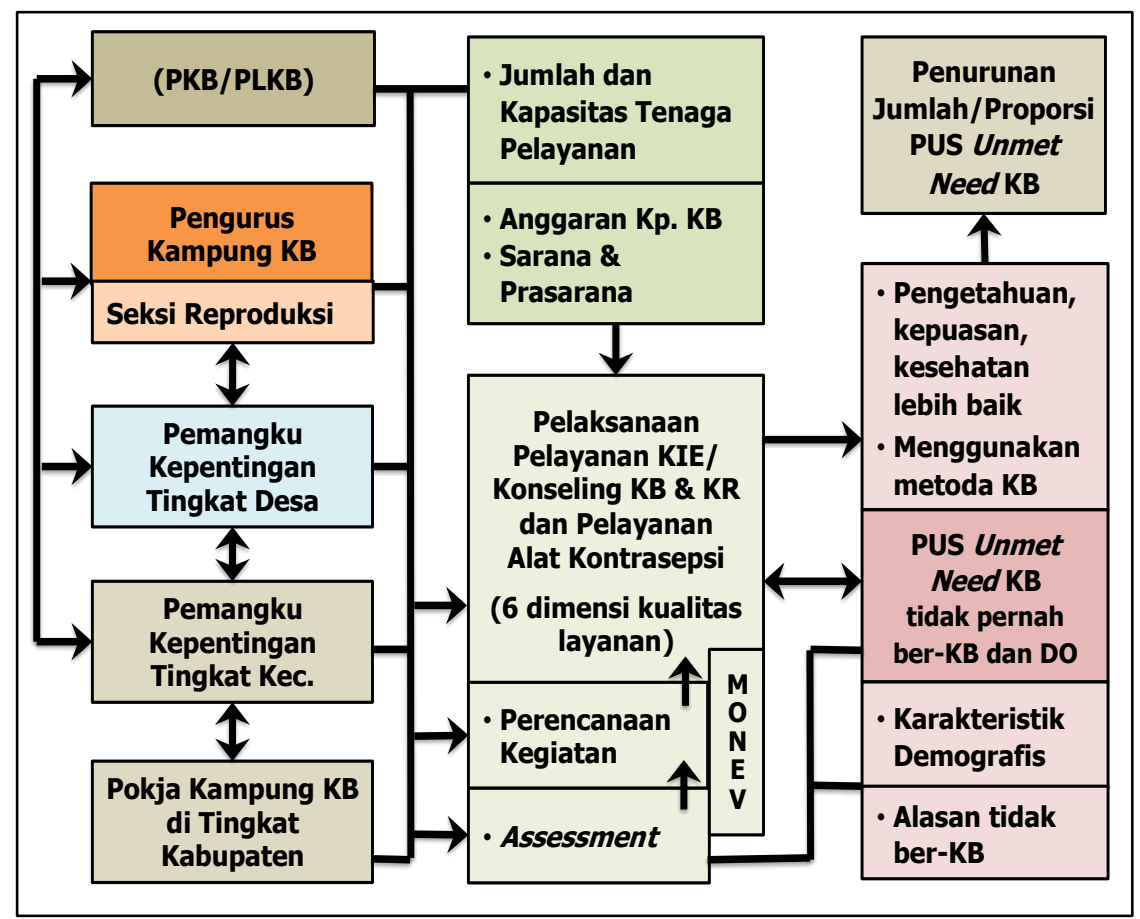

\section{PEMBAHASAN}

\section{Perkembangan Kampung KB di lokasi penelitian}

Di Kabupaten Cianjur, pembentukan Kampung KB dimulai dengan membentuk satu Kampung KB di setiap kecamatan pada awal tahun 2017. Kampung KB RW 04 Desa Mulyasari Kecamatan Cilaku terbentuk pada tanggal 22 Maret 2017 dan Kampung KB RW 05 Desa Kertasari Kecamatan Haurwangi terbentuk pada tanggal 12 Juli 2017. Pembentukan Kampung KB ini ditandai dengan terbentuknya pengurus Kampung KB yang terdiri dari delapan seksi, termasuk Seksi Reproduksi. Bidang yang diurus oleh tiap seksi ini terkait langsung dengan delapan fungsi keluarga.

Sayangnya di setiap kecamatan hanya ada satu Kampung KB. Padahal, pemerintah Kabupaten Cianjur menginginkan keberadaan kampung yang serupa dengan Kampung KB di tiap RW. Oleh karena itu, pada tahun yang sama pemerintah daerah Kabupaten Cianjur membentuk Kampung Kuba, yaitu Kampung Keluarga Berakhlaqul Karimah, yang mengusung tujuh pilar kebudayaan, tujuh gerakan keagamaan, dan tujuh fungsi keluarga (sama dengan delapan fungsi keluarga Kampung KB tetapi dua fungsi keluarga digabungkan).

Kampung KB dan Kampung Kuba memiliki tujuan yang sama yaitu membangun keluarga. Program
Kampung Kuba mendapat dukungan anggaran dari ADD dan dana RT/RW. Agar Kampung KB mendapat dukungan anggaran yang sama dari Pemerintah Daerah Kabupaten Cianjur, status Kampung Kuba pun disandangkan pada Kampung KB. Oleh karena itu, pengurus Kampung KB di Kabupaten Cianjur mengemban tugas program Kampung $\mathrm{KB}$ sekaligus program Kampung Kuba.

Walaupun kedua Kampung KB ini telah terbentuk pada pertengahan tahun 2017, kegiatan operasional baru dimulai pada awal tahun 2018. Hal ini terkait dengan ketersediaan dana yang baru terealisasi pada awal tahun 2018. Terkait dengan pelaksanaan Program Keluarga Berencana dan Kesehatan Reproduksi (KB dan KR), Seksi Reproduksi yang memiliki fungsi ini belum banyak terlibat. Hal ini disebabkan oleh seringnya pergantian pemegang jabatan Seksi Reproduksi; ada yang mengundurkan diri karena merasa tidak cocok, dan ada juga yang masih belum memahami tugasnya.

Jika merujuk pada Buku Pedoman Pengelolaan Kampung KB, tugas Seksi Reproduksi meliputi (i) memotivasi PUS untuk ber-KB; (ii) membina kelangsungan ber-KB; (iii) menyelenggarakan pembentukan, pembinaan dan pengembangan posyandu; (iv) membuat peta keluarga tiap RT; (v) mendidik keluarga tentang kesehatan reproduksi dan 
reproduksi remaja; (vi) pembentukan PIK Remaja dan Kampanye PUP; (vii) melaksanakan pelayanan KB; (viii) melaksanakan rujukan dan pengayoman medis; (ix) penyediaan alat kontrasepsi bagi yang tidak mampu; (x) mengkoordinasikan layanan dan pembinaan peserta KB dengan dokter dan bidan swasta; (xi) pelayanan papsmear, pemeriksaan bumil dan imunisasi di Posyandu; dan (xii) mengusahakan hal-hal yang dibutuhkan bidang reproduksi kepada pemerintah yang lebih atas, dalam hal ini desa, kecamatan, kabupaten, dan seterusnya (BKKBN, 2017:30-31).

Tugas terakhir, secara khusus, memerlukan kualifikasi tertentu dari pejabatnya. Padahal, di tingkat RW di wilayah pedesaan, orang yang memiliki kualifikasi yang dapat melaksanakan tugas tersebut relatif terbatas. Ketua Kampung KB di RW 05 Desa Kertasari pun belum merumuskan rincian tugas untuk Seksi Reproduksi. Hal yang wajar apabila Seksi Reproduksi masih belum terlibat dalam kegiatan operasional KB dan kesehatan reproduksi.

Di pihak lain, di Kampung KB RW 04 Desa Mulyasari sudah ada rincian tugas untuk Seksi Reproduksi, sama persis dengan apa yang tertera di Buku Pedoman Kampung KB. Pejabatnya adalah seorang kader Posyandu. Meskipun begitu, pejabat Seksi Reproduksi sampai saat ini belum memahami tugasnya.

Walaupun demikian, kegiatan operasional Program KB dan KR di kedua Kampung KB ini terus berjalan. Di Kampung KB RW 05 Desa Kertasari, kader Posyandu, bidan desa, tenaga penggerak pengintegrasian layanan sosial (PPL) Posyandu, pembantu pembina KB desa (PPKBD), dan PKB/PLKB masih bekerjasama dalam melaksanakan kegiatan program KB dan KR. PPL Posyandu adalah tenaga penggerak yang direkrut oleh pemerintah daerah Kabupaten Cianjur yang ditempatkan di desa untuk membantu menyukseskan program peningkatan Posyandu yang cakupan kerjanya tidak lagi mengenai keluarga berencana (KB), tetapi juga meliputi ketahanan pangan, kesejahteraan sosial, perlindungan anak, serta menekan angka kematian ibu dan anak.

Demikian juga di Kampung KB RW 04 Desa Mulyasari, kegiatan operasional Program KB dan KR terus berjalan, walaupun keberadaan PKB/PLKB di desa ini sempat tidak ada, dan baru ada lagi pada bulan Oktober 2018. Jumlah PKB/PLKB di Kabupaten
Cianjur memang sangat terbatas. Walaupun di Provinsi Jawa Barat disubstitusi oleh tenaga penggerak KB desa (TPD-KB), tetapi jumlahnya belum sebanding dengan jumlah desa yang ada. Saat ini PKB/PLKB di Desa Kertasari memegang tiga desa, sementara PKB/PLKB di Desa Mulyasari memegang dua desa. PPKBD di Desa Mulyasari yang ada saat ini pun adalah petugas baru, sehingga pada saat penelitian ini dilakukan, ia tidak mengetahui bagaimana program KB yang dilakukan sebelumnya.

Keberadaan PKB/PLKB dan PPKBD di kedua Kampung KB ini memengaruhi tingkat kesertaan PUS ber-KB, termasuk di dalamnya PUS unmet need KB. Hasil Pendataan Keluarga tahun 2015 di Kampung KB RW 05 Desa Kertasari tingkat unmet need KB (13 PUS dari 144 PUS) jauh lebih rendah daripada di Kampung KB RW 04 Desa Mulyasari (133 PUS dari 377 PUS). Merujuk pada data ini, pada saat kedua Kampung KB tersebut dibentuk masing-masing menghadapi kondisi tingkat unmet need $\mathrm{KB}$ yang berbeda.

\section{Proses assessment (Identifikasi PUS unmet need KB)}

Sebagaimana dijelaskan sebelumnya, kualitas layanan $\mathrm{KB}$ yang baik memerlukan proses sistematis berbasis fakta (PATH UNFPA, 2008). Untuk itu, penting untuk melakukan kegiatan assessment untuk menentukan sasaran layanan dan faktor yang menyebabkan PUS mengalami unmet need $\mathrm{KB}$.

Jika merujuk pada definisi yang dikembangkan oleh Bradley dkk. (2012) (Gambar 2), identifikasi PUS unmet need $\mathrm{KB}$ memerlukan cakupan data meliputi: (i) kesertaan ber-KB (sedang/tidak menggunakan kontrasepsi; (ii) data kehamilan (sedang/tidak hamil); (iii) umur anak terakhir (kurang dari dua tahun); (iv) PUS mendapat haid kurang dari dua tahun setelah melahirkan; dan (v) keinginan memiliki anak meliputi ingin anak segera (IAS), ingin anak tetapi ditunda (IAD), dan tidak ingin anak agi (TIAL). Data kehamilan dan PUS yang mendapat haid kurang dari dua tahun setelah melahirkan, khususnya, digunakan untuk mengindikasikan wanita subur atau tidak subur. 
Gambar 2. Definisi wanita unmet need KB

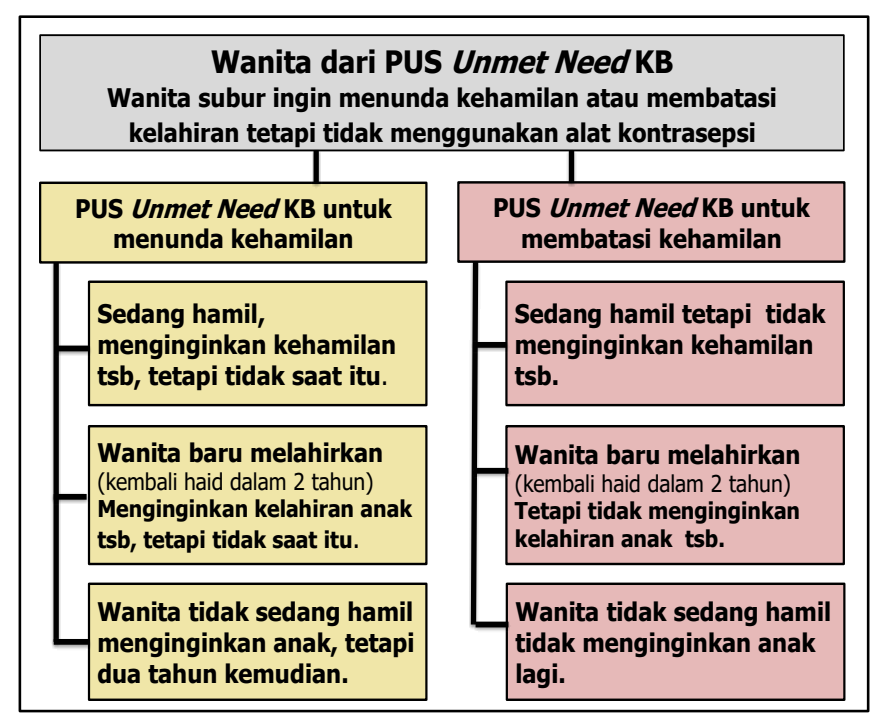

Sumber: Bradley (2012)

Kombinasi data antara kehamilan/kelahiran anak dan IAS dikategorikan sebagai kelompok yang tidak termasuk unmet need KB. Sementara itu, kombinasi data antara kehamilan/kelahiran anak dan IAD menunjukkan kehamilan/kelahiran anak yang tidak diinginkan pada saat itu. Selanjutnya, kombinasi antara data kehamilan/kelahiran anak dengan TIAL mengindikasikan kehamilan/kelahiran anak yang tidak diinginkan.

Selain untuk mengidentifikasi PUS unmet need $\mathrm{KB}$, data untuk kepentingan pelayanan $\mathrm{KIE} /$ konseling $\mathrm{KB}$ juga diperlukan, yang meliputi (i) umur wanita PUS; (ii) jumlah anak lahir hidup; (iii) jumlah anak meninggal; (iv) umur anak terkecil; (v) alasan tidak menggunakan kontrasepsi; dan (vi) pendidikan. Data umur wanita PUS, jumlah anak lahir hidup dan meninggal, serta data umur anak terkecil digunakan untuk mengidentifikasi wanita PUS “empat terlalu” yang merupakan kelompok sasaran prioritas; sedangkan data terkait alasan tidak menggunakan kontrasepsi digunakan untuk penyiapan materi KIE/konseling KB.

Untuk mengidentifikasi PUS unmet need KB tersebut diperlukan sumber data. Di Kampung KB di Kabupaten Cianjur terdapat empat jenis sumber data, meliputi (i) buku "RR Aneka" - buku pencatatan data PUS yang harus diisi oleh PPKBD; (ii) buku Register WUS dan PUS dalam sistem informasi Posyandu yang harus diisi oleh kader Posyandu; (iii) buku pendataan untuk
Kampung Kuba, di antaranya informasi tentang "keluarga ikut merencanakan kelahiran anak"; dan (iv) lembar F/1/PK yang digunakan pada Pendataan Keluarga (PK) oleh BKKBN.

Ketersediaan data yang terkandung dalam keempat instrumen pencatatan data tersebut berbeda-beda (Tabel 2), dengan cara pencatatan yang berbeda pula. Dari empat jenis sumber data tersebut, hanya pencatatan keluarga Kampung Kuba dan lembar F/I/PK yang dapat mengidentifikasi PUS unmet need $\mathrm{KB}$, dengan prasyarat bahwa pengisian dilakukan secara lengkap. Pada lembar F/I/PK, data karakteristik PUS untuk kebutuhan KIE/Konseling KB pun tersedia. Namun demikian, kedua instrumen pencatatan data PUS ini tidak digunakan sehari-hari. Lembar P/1/PK digunakan secara periodik (tahunan).

Instrumen pengumpulan data yang digunakan sehari-hari di lapangan saat ini adalah buku register WUS dan PUS dalam sistem informasi Posyandu yang diisi oleh kader Posyandu dan buku "RR Aneka" yang diisi oleh PPKBD. Agar dapat memenuhi cakupan data untuk dapat mengidentifikasi PUS unmet need $\mathrm{KB}$ dan untuk mendukung kebutuhan KIE/Konseling KB maka diperlukan penambahan data. Agar tidak tumpang tindih dan lebih efektif, akan lebih baik jika instrumen pencatatan data PUS untuk kebutuhan pelayanan KB ini hanya satu saja. Pengisiannya dilakukan secara bersama-sama dan hasilnya dapat digunakan oleh semua pihak. Dalam merevisi instrumen pengumpulan data ini, cakupan data (PK) dapat menjadi rujukan. Jika instrumen ini sudah selaras dengan cakupan data PK, maka ketika ada pemutakhiran data PK, data PUS ini dapat digunakan.

Selain kelengkapan data, yang perlu diperhatikan juga adalah cara pencatatan agar data tersebut dapat dengan mudah diolah untuk kepentingan pelayanan dan evaluasi menggunakan bantuan aplikasi komputer. Cara pencatatan seperti pada buku 'RR Aneka' dapat menjadi contoh. Hal ini dikarenakan pencatatan PUS akseptor KB pada buku ini dipilah berdasarkan jenis alat kontrasepsi dan PUS yang tidak menggunakan kontrasepsi dicatat pada buku yang berbeda. Oleh karena itu, jika terjadi perubahan status kesertaan ber$\mathrm{KB}$ dapat dengan mudah terlihat. 
Tabel 2. Ketersediaan data PUS pada empat instrumen pencatatan data PUS

\begin{tabular}{|c|c|c|c|c|c|c|}
\hline \multirow{3}{*}{ No. } & \multirow{3}{*}{ Jenis Data } & \multirow{3}{*}{$\begin{array}{c}\begin{array}{c}\text { Data PUS } \\
\text { RR Aneka }\end{array} \\
\begin{array}{c}\text { Bukan } \\
\text { Akseptor }\end{array}\end{array}$} & \multirow{3}{*}{$\begin{array}{c}\text { Data WUS } \\
\text { \& PUS } \\
\text { SIP } \\
\text { Bukan } \\
\text { Akseptor }\end{array}$} & \multirow{3}{*}{$\begin{array}{c}\begin{array}{c}\text { Data } \\
\text { Kelrg } \\
\text { Kp. Kuba }\end{array} \\
\begin{array}{c}\text { Bukan } \\
\text { Akseptor }\end{array}\end{array}$} & \multicolumn{2}{|c|}{$\begin{array}{c}\text { Pendataan Keluarga } \\
\text { BKKBN }\end{array}$} \\
\hline & & & & & \multicolumn{2}{|c|}{ Bukan Akseptor } \\
\hline & & & & & $\begin{array}{c}\text { Pernah } \\
\text { KB }\end{array}$ & Blm Pernah \\
\hline 1 & Alamat RT/RW & $\checkmark$ & - & $\checkmark$ & $\checkmark$ & $\checkmark$ \\
\hline 2 & Nama Suami & $\checkmark$ & $\checkmark$ & - & $\checkmark$ & $\checkmark$ \\
\hline 3 & Nama Isteri & $\sqrt{ }$ & $\checkmark$ & - & $\checkmark$ & $\checkmark$ \\
\hline 4 & Umur Isteri & $\checkmark$ & $\checkmark$ & - & $\checkmark$ & $\checkmark$ \\
\hline 5 & Jumlah Anak & $\checkmark$ & - & - & $\checkmark$ & $\checkmark$ \\
\hline 6 & Jumlah Anak hidup & - & $\checkmark$ & - & $\checkmark$ & $\checkmark$ \\
\hline 7 & $\begin{array}{ll}\text { Jumlah } & \text { Anak } \\
\text { Meninggal } & \end{array}$ & - & $\checkmark$ & - & $\checkmark$ & $\checkmark$ \\
\hline 8 & Umur Anak Terkecil & - & - & - & - & - \\
\hline 9 & Kesertaan Ber-KB & $\checkmark$ & $\checkmark$ & $\checkmark$ & $\checkmark$ & $\checkmark$ \\
\hline 10 & Jenis Kontrasepsi & - & - & - & $\checkmark$ & - \\
\hline 11 & $\begin{array}{l}\text { Pergantian Kontrasepsi } \\
\text { (Tanggal dan Jenis) }\end{array}$ & - & - & - & - & - \\
\hline 12 & Hamil/Tidak Hamil & $\checkmark$ & - & $\checkmark$ & - & - \\
\hline 13 & IAS / IAD/TIAL & - & - & $\checkmark$ & $\sqrt{ }$ & $\sqrt{ }$ \\
\hline 14 & Alasan Tidak KB & $\checkmark \square *)$ & - & - & $\boldsymbol{V} \square * *)$ & $\checkmark \square * *)$ \\
\hline 15 & Tahapan KS & $\checkmark$ & $\checkmark$ & - & $\checkmark$ & $\checkmark$ \\
\hline 16 & Pembinaan per Bulan & - & - & - & - & - \\
\hline 17 & Nama Posyandu & - & $\checkmark$ & - & - & - \\
\hline 18 & Kelompok Dasawisma & - & $\checkmark \neg * * *)$ & - & - & - \\
\hline 19 & Nama KK & - & - & $\sqrt{ }$ & - & - \\
\hline 20 & $\begin{array}{ll}\text { Jml } & \text { Keluarga/Peserta } \\
\text { KB } & \end{array}$ & - & - & & - & - \\
\hline 21 & $\begin{array}{l}\text { Jml Keluarga/Peserta } \\
\text { Tidak Ber-KB }\end{array}$ & - & - & $\checkmark$ & - & - \\
\hline & Jumlah Jenis Data & 8 & 7 & 5 & 12 & 11 \\
\hline
\end{tabular}

Keterangan:

\begin{tabular}{l} 
Data untuk mengidentifikasi PUS Unmet Need KB \\
Data yang mendukung Penanganan Unmet Need KB \\
\hline *) Saat ini alasan tidak KB diisi dengan IAS/IAD/TIAL \\
**) Salah satu alasan 'sedang hamil' \\
***) Saat ini data tidak terisi \\
Sumber: Hasil olah data
\end{tabular}

Dalam proses pencatatan data, terdapat beberapa pihak yang terlibat, seperti yang terlihat pada Gambar 3. Dapat dicermati bahwa yang bertugas mencatat data hanya kader Posyandu yang mengisi buku register WUS dan PUS dan PPKBD yang mengisi Buku "RR Aneka". Buku "RR Anek" hanya ada di Desa Kertasari Kecamatan Haurwangi, sementara di Desa Mulyasari Kecamatan Cilaku belum ada instrumen pengumpulan data yang digunakan sehari-hari oleh PPKBD. PPKBD hanya mencatat data yang bersumber dari hasil pencatan data yang dilakukan oleh kader Posyandu. Para petugas dari institusi lainnya hanya memberikan fasilitasi informasi.
Data rujukan yang digunakan untuk penentuan lokasi Kampung KB menurut informasi yang diperoleh dari dokumen yang ada di Dinas PPKBP3A Kabupaten Cianjur (2017) menggunakan data PK 2015 (Tabel 3). Untuk kegiatan operasional Kampung KB, pada tahun 2017 dilakukan pemutakhiran data. Hasil pemutakhiran data di Kampung KB RW 04 Desa Mulyasari tercantum dalam dokumen Profil Kampung KB RW 04 Desa Mulyasari. Jumlah PUS unmet need KB tahun 2015 dengan tahun 2017 tampak jauh berbeda. Artinya selama dua tahun tersebut sudah terjadi pengurangan jumlah PUS unmet need KB. Sementara itu, di Kampung KB RW 05 Desa Kertasari, data untuk tahun 2017 diperoleh dari PKB/PLKB Desa Kertasari yang 
menunjukkan jumlah unmet need sebesar 17 PUS. Dengan kata lain, terdapat penambahan tiga PUS dibandingkan dengan data PK tahun 2015.

Gambar 3. Kolaborasi antar institusi dalam pencatatan data PUS

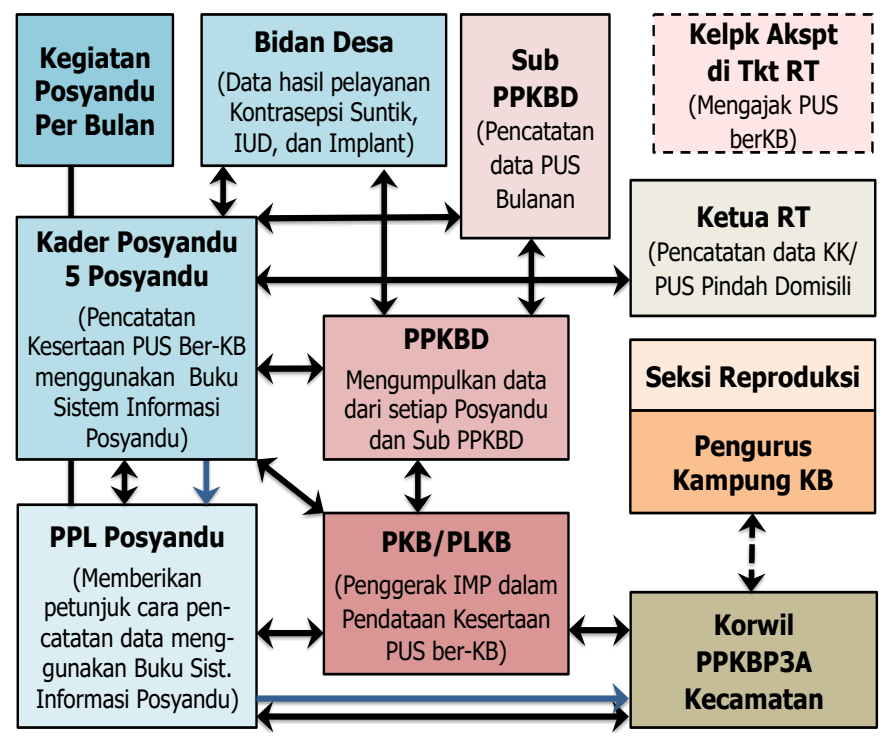

Keterangan:

- Tanda panah dua arah: relasi kerjasama

- Tanda panah satu arah : pelaporan data

- Petugas yang ditulis dalam kotak bergaris tepi putus-

putus belum ada tetapi direncanakan akan ada

Sumber: Hasil olah data

Tabel 3. Ketersediaan data PUS unmet need KB

\begin{tabular}{|c|c|c|c|c|}
\hline \multirow{2}{*}{$\begin{array}{c}\text { Keterangan } \\
\text { PUS Unmet } \\
\text { Need KB }\end{array}$} & \multicolumn{2}{|c|}{$\begin{array}{c}\text { Kp. KB RW } 04 \\
\text { Desa Mulyasari } \\
\text { Kec. Cilaku }\end{array}$} & \multicolumn{2}{|c|}{$\begin{array}{c}\text { Kp. KB RW } 05 \\
\text { Desa Kertasari } \\
\text { Kec. Haurwangi }\end{array}$} \\
\hline & $\begin{array}{c}2015 \\
*)\end{array}$ & $\begin{array}{c}2017 \\
* *)\end{array}$ & $\begin{array}{c}2015 \\
*)\end{array}$ & $\begin{array}{c}2017 \\
* *)\end{array}$ \\
\hline IAD & 36 & 22 & 10 & $?$ \\
\hline TIAL & 97 & 33 & 3 & $?$ \\
\hline Jumlah & 133 & 55 & 13 & 17 \\
\hline Data Mikro & \multirow{4}{*}{$\begin{array}{l}\text { Tidak } \\
\text { memi- } \\
\text { liki }\end{array}$} & \multirow{4}{*}{$\begin{array}{l}\text { Dokumen } \\
\text { tidak } \\
\text { ditemukan }\end{array}$} & Ada & Ada \\
\hline $\begin{array}{l}\text { Alasan } \\
\text { tidak } \\
\text { menggunakan } \\
\text { kontrasepsi }\end{array}$ & & & $\begin{array}{l}\text {-Sedang } \\
\text { Hamil (4) } \\
\text {-Fertilitas } \\
\text { (1) } \\
\text {-Lainnya } \\
\text { (8) }\end{array}$ & \multirow[t]{3}{*}{$\begin{array}{l}\text { Doku- } \\
\text { men } \\
\text { tidak } \\
\text { diterima } \\
\text { oleh } \\
\text { peneliti }\end{array}$} \\
\hline Umur Isteri & & & Ada & \\
\hline Jumlah Anak & & & Tidak ada & \\
\hline
\end{tabular}

Keterangan:

*) Data PK 2015, bersumber dari Dinas PPKBP3A Kab. Cianjur

**) Data pada saat Pembentukan Kampung KB

Sumber: Hasil olah data
Menurut pernyataan PKB/PLKB di Desa Kertasari, pada saat pemutakhiran data setelah Kampung KB terbentuk, PKB/PLKB tidak dilibatkan dalam proses tersebut. Semua proses terkait ditangani langsung oleh koordinator wilayah PPKBP3A bersama dengan kader di lapangan. Oleh karena itu, data PUS unmet need $\mathrm{KB}$ yang dimiliki oleh PKB/PLKB tersebut adalah hasil pencatatannya sendiri.

Di dalam dokumen hasil pencatatan data PUS tahun 2017 hanya tersedia jumlahnya saja, tidak tersedia dokumen data mikronya, sehingga tidak dapat diketahui siapa dan dimana PUS unmet need KB tersebut berada. Di Kampung KB RW 04 Mulyasari tidak diperoleh informasi apakah data ini digunakan sebagai data basis untuk pelayanan KIE/Konseling KB oleh para petugas di lapangan atau tidak, karena informan PKB/PLKB dan PPKBD yang bertugas sebelum penelitian ini dilakukan sudah pensiun. PKB/PLKB dan PPKBD yang bertugas saat ini tidak mengetahuinya. Oleh karena dokumen data mikro PUS unmet need KB 2017 tidak tersedia, perubahan status PUS unmet need KB tersebut tidak dapat ditelusuri.

Menurut pernyataan PKB/PLKB, data mikro tahun 2017 di Kampung KB RW 05 tersedia. Namun, dokumen data tersebut tidak dapat diperoleh. Ketika peneliti meminta data mikro unmet need $\mathrm{KB}$ hasil pencatatan pada saat Kampung KB dibentuk, untuk keperluan informan PUS, diperoleh daftar PUS atau data mikro yang bersumber dari data PK 2015. Dalam daftar PUS tersebut, selain tercantum 13 nama PUS yang termasuk IAD dan TIAL (unmet need $\mathrm{KB}$ ), ada juga nama-nama PUS yang IAS atau 'ingin anak segera'. Kondisi ini bisa jadi karena ketidaksengajaan dalam proses pengisian, tetapi dapat juga mengindikasikan hal lain yang lebih mengkhawatirkan yaitu pemahaman yang salah terhadap konsep unmet need $\mathrm{KB}$.

\section{Proses perencanaan kegiatan KIE/konseling KB}

Dalam Buku Pedoman Kampung KB, petugas KIE/Konseling KB adalah PKB, PPKBD, sub-PPKBD, dan kader Posyandu. Di Kabupaten Cianjur terdapat pula petugas lini lapangan lain yaitu PPL Posyandu yang salah satu tugasnya adalah melakukan KIE/konseling KB. Berdasarkan informasi dari Kader Posyandu, PPKBD, dan PPL Posyandu di kedua Kampung KB tidak ada kegiatan khusus untuk 
pembuatan rencana kegiatan KIE/konseling KB. Kader Posyandu dan PPKBD, dengan berbekal data yang dimiliki, memfokuskan perhatian pada PUS yang tidak menggunakan alat kontrasepsi, apakah PUS tersebut termasuk unmet need $\mathrm{KB}$ atau tidak. Kader Posyandu tidak memiliki data PUS unmet need $\mathrm{KB}$, karena dalam pencatatan data yang dimilikinya, PUS unmet need KB tidak teridentifikasi. PPKBD di Kampung KB RW 05 Desa Kertasari memiliki data PUS IAD dan TIAL tetapi tidak memiliki data 'alasan PUS tidak menggunakan kontrasepsi'. Dengan demikian, PPKBD pun tidak dapat menyiapkan bahan untuk KIE/konseling $\mathrm{KB}$. Data PUS IAD dan TIAL yang tidak menggunakan alat kontrasepsi pun belum secara spesifik dijadikan rujukan untuk mempersiapkan kegiatan KIE/konseling KB. PPKBD belum paham bahwa PUS tersebut merupakan sasaran layanan prioritas dan mereka adalah pihak yang paling memerlukan pelayanan KIE/konseling KB.

Data 'alasan tidak menggunakan alat kontrasepsi' penting untuk diketahui untuk mempersiapkan materi kegiatan KIE/konseling KB. Setiap alasan yang dikemukakan oleh PUS menunjukkan kebutuhan layanan informasi yang berbeda. Berdasarkan data ini, PUS dengan alasan yang sama dapat dikelompokkan. Petugas penyuluh dapat mempersiapkan materi KIE lebih spesifik dan dapat dibahas secara mendalam, Situasi ini, pada akhirnya, diharapkan dapat menguntungkan sasaran layanan sebab mereka dapat memperoleh informasi yang lengkap sesuai kebutuhan dalam waktu yang singkat.

Sebagai contoh, di Kampung KB RW 04 Desa Mulyasari sedikitnya terdapat sembilan PUS yang tidak menggunakan alat/metode kontrasepsi karena alasan agama dan mereka semua termasuk kategori unmet need KB (PUS IAD dan TIAL); diantaranya ada yang masih berumur kurang dari 40 tahun tetapi sudah memiliki anak 12 orang. Walaupun mereka menyatakan alasan tidak menggunakan alat kontrasepsi karena alasan agama, tetapi ada juga PUS yang ditemukan pernah menggunakan alat/metode kontrasepsi tertentu, karena mereka merasa perlu ataupun karena mengabaikan larangan agama yang diyakininya. Pada kelompok PUS dengan situasi seperti ini, KIE kelompok dianjurkan untuk dilakukan. Tenaga penyuluhnya dapat dipilih dari kalangan pemuka agama yang dapat menjelaskan manfaat alat/metode kontrasepsi dari sisi agama, dalam hal ini agama Islam.
Pemahaman mengenai berbagai jenis alat kontrasepsi yang sesuai dengan kondisi mereka masing-masing kemudian dapat pula diberikan. KIE kelompok merupkan solusi yang efisien dalam kerangka keterbatasan waktu dan petugas. Walaupun $\mathrm{KIE} /$ Konseling KB individual dianggap lebih efektif, KIE Kelompok dapat efektif jika PUS sasaran sudah terpilah berdasarkan kebutuhan informasi yang sama; karena bagi PUS yang tidak aktif bertanya dapat terbantu oleh PUS yang aktif bertanya.

\section{Proses pelaksanaan kegiatan KIE/konseling KB}

Merujuk pada konsep kualitas layananan yang dikemukakan oleh Bruce (1990), sedikitnya ada enam aspek yang perlu dijelaskan dalam KIE/konseling KB, yaitu (i) pilihan metode kontrasepsi; (ii) kejelasan informasi yang diberikan kepada klien; (iii) kompetensi teknis penyedia layanan; (iv) hubungan interpersonal antara penyedia layanan dan klien; (v) tindak lanjut dan kontinuitas layanan; dan (vi) konstelasi layanan yang ditawarkan. Menurut penjelasan kader Posyandu, pelaksanaan kegiatan KIE/konseling KB di kedua RW Kampung KB ini dilakukan oleh kader Posyandu yang memiliki waktu dan yang dianggap memiliki kemampuan untuk melakukan KIE/konseling $\mathrm{KB}$, bersama dengan atau tanpa PPKBD atau PKB melakukan kunjungan rumah PUS sasaran yang tidak menggunakan alat/metode kontrasepsi atau yang ingin beralih ke alat kontrasepsi lain.

Ketika melakukan kunjungan rumah, kader Posyandu biasanya juga mengajak PUS pengguna alat kontrasepsi tertentu yang masih belum banyak diminati, seperti pengguna implant, IUD, atau MOP, untuk berbagi informasi tentang pengalaman mereka. Sebagai contoh, seorang kader Posyandu di RT 04 Kampung KB RW 04 Desa Mulyasari yang juga sebagai akseptor KB pengguna implant, atau rekan kader Posyandu lainnya yang menggunakan MOW. Jika mereka mengunjungi PUS sasaran, biasanya mereka menceritakan apa yang dialami dan dirasakan ketika menggunakan alat kontrasepsi tersebut dan bagaimana cara memperolehnya. Menurut mereka, cara ini biasanya lebih efektif untuk mengajak PUS menggunakan alat kontrasepsi karena informasi diperoleh dari pengguna.

Kegiatan KIE/konseling KB oleh kader Posyandu jarang dilakukan di Posyandu, karena biasanya kegiatan penyuluhan lebih banyak dilakukan untuk kesehatan 
balita. Selain itu, ibu balita biasanya tidak banyak yang hadir pada kegiatan Posyandu, karena biasanya mereka sedang sibuk bekerja di lahan pertanian atau sebagai buruh tani. Selain itu, semua Posyandu belum memiliki tempat khusus atau gedung sendiri. Bidan desa juga selalu memberikan informasi tentang pentingnya penggunaan alat/metode kontrasepsi pada ibu bersalin selepas persalinan. Bidan biasanya menganjurkan ibu bersalin menggunakan salah satu alat/metode kontrasepsi tertentu untuk menjarangkan atau menghentikan kehamilan. PUS sasaran umumnya mendapatkan pemahaman yang cukup baik mengenai berbagai alat kontrasepsi berdasarkan penjelasan dari kader Posyandu maupun dari bidan desa. Namun demikian, pengambilan keputusan untuk menggunakan atau tidak menggunakan alat kontrasepsi dan pemilihan alat kontrasepsinya sangat tergantung pada PUS sendiri.

Pengambilan keputusan PUS untuk menggunakan salah satu alat kontrasepsi biasanya ada yang mudah/cepat dan ada juga yang sulit/lama. Proses pengambilan keputusan yang memerlukan waktu lama terutama untuk memutuskan penggunaan metode kontrasepsi IUD, implan, dan MOW. Hal ini terkait dengan cara penanganannya. Cara pemasangan IUD bagi sebagian besar PUS dirasakan tidak nyaman dan umumnya mereka merasa malu dan risih. Walaupun penanganannya tidak jauh berbeda dengan ketika mereka bersalin, tetapi menurut mereka situasi ketika bersalin dan ketika pelayanan kontrasepsi tersebut berbeda.

Metoda kontrasepsi implant, sepertinya mulai diminati, karena ada beberapa kader Posyandu dan PUS yang sudah menggunakannya dan mereka berbagi pengalaman dengan PUS lainnya. Selain itu, saat ini alat kontrasepsi implan, MOW, dan IUD merupakan metoda kontrasepsi pemerintah yang banyak ditawarkan dan tidak berbayar. Kalaupun berbayar biayanya murah dan dapat dengan mudah dijangkau oleh PUS di kedua Kampung KB ini. Pil dan suntik merupakan jenis kontrasepsi lainnya yang banyak digunakan oleh PUS lainnya. Kerap ditemukan PUS yang pada awalnya mencoba alat kontrasepsi tertentu dan jika merasa tidak cocok dapat dengan mudah beralih ke alat kontrasepsi lain, seperti pengalaman salah satu wanita PUS yang menggunakan alat kontrasepsi berganti-ganti antara pil dan suntik.

\section{Proses pelaksanaan kegiatan pelayanan kontrasepsi}

Pelayanan kontrasepsi sangat berkaitan dengan Pelayanan KIE/konseling KB. Keputusan PUS untuk menggunakan atau tidak menggunakan alat kontrasepsi dapat dipengaruhi oleh pelayanan KIE/konseling KB. Saat ini, pelayanan kontrasepsi di kedua Kampung KB relatif mudah diperoleh. Pelayanan alat kontrasepsi pil, dapat diperoleh di kader Posyandu atau PPKBD (untuk alat kontrasepsi pil Pemerintah) atau dapat dibeli sendiri di toko atau apotik. Pelayanan alat kontrasepsi suntik dapat diperoleh dari bidan desa dan bidan lain di desa tersebut yang membuka layanan alat kontrasepsi. Pelayanan alat kontrasepsi implan dan IUD biasanya diperoleh dari pelayanan kontrasepsi yang diselenggarakan pemerintah daerah melalui kegiatan pelayanan safari KB di Puskesmas atau Puskesmas Pembantu atau melalui kegiatan pelayanan kontrasepsi di tingkat kabupaten. Pelayanan kontrasepsi MOW, secara khusus, hanya dapat diperoleh di rumah sakit tertentu yang memiliki dokter spesialis terlatih. PUS di Kabupaten Cianjur dapat memperolehnya melalui kegiatan safari KB yang diselenggarakan oleh pemerintah daerah Kabupaten Cianjur.

Dari sisi pembiayaan, penyelenggaraan pelayanan kontrasepsi pemerintah untuk alat kontrasepsi IUD dan implan di Puskesmas atau Puskesmas Pembantu berbeda denga penyelenggaraan di tingkat kabupaten yang kelompok sasarannya untuk semua PUS di wilayah Kabupaten Cianjur. Jika diselenggarakan di Puskesmas atau Puskesmas Pembantu setempat, sejumlah pembiayaan ada yang ditanggung oleh PUS peserta layanan, termasuk di dalamnya layanan alat kontrasepsi implant. Meskipun alat implannya disediakan oleh pemerintah, tetapi obat penangkal efek samping pasca pelayanannya harus ditanggung oleh PUS. Oleh karena itu, PUS biasanya dikenakan biaya dalam jumlah tertentu. Kader Posyandu dalam kajian ini mengemukakan bahwa biaya pelayanan alat kontrasepsi implan, jika dilakukan di Puskesmas Pembantu sebesar Rp 35.000,- untuk tiga tahun masa pemakaian, jauh lebih murah jika dibandingkan dengan biaya alat kontrasepsi suntik, Rp 25.000,- untuk tiga bulan. Namun, fasilitas ini belum dimanfaatkan di kedua Kampung KB di Kabupaten Cianjur karena masih ada yang merasa takut menggunakannya. Situasi ini merupakan tantangan bagi para petugas 
$\mathrm{KIE} /$ konseling untuk terus memasyarakatkan alat/metode kontrasepsi ini.

Alat kontrasepsi yang banyak dipilih di Kampung KB RW 04 Desa Mulyasari maupun di Kampung KB RW 05 Desa Kertasari adalah suntik dan pil. Meskipun begitu, metoda kontrasepsi implan, sepertinya mulai diminati, karena sudah ada beberapa kader Posyandu dan PUS yang sudah memakai metode kontrasepsi ini dan mereka berbagi pengalaman dengan PUS lainnya.

Kelembagaan yang terlibat dalam kegiatan pencatatan data untuk mengidentifikasi kelompok sasaran PUS unmet need $\mathrm{KB}$, pelayanan $\mathrm{KIE} /$ konseling $\mathrm{KB}$, serta pelayanan kontrasepsi cukup banyak. Keberadaan mereka merupakan sumber daya atau modal sosial komunitas yang dapat digunakan untuk mengembangkan program KB dan kesehatan reproduksi di Kampung KB. Namun demikian, kapasitas mereka perlu ditingkatkan.

Dalam melaksanakan tugasnya, kelembagaan terkait memerlukan otonomi yaitu kekuatan yang dimiliki untuk mengekspresikan kedudukannya secara efektif; dalam hal ini kapasitas yang memadai untuk mendukung otonomi mereka. Sebagai relawan, mereka juga perlu memiliki rasa solidaritas, kedermawanan, dan kerelawanan. Hal ini perlu terus dipupuk dan dikembangkan dengan memperhatikan return on investment atau keuntungan atas investasi yang telah mereka tanamkan agar mereka mau terus terlibat, keuntungan yang diperoleh tidak selalu dalam bentuk materi atau uang. Selain itu, dalam melaksanakan tugasnya mereka memerlukan kejelasan tugas atau peran yang harus dimainkan; seyogyanya ada aturan dan prosedur yang disepakati bersama yang berisi pembagian tugas dan relasi diantara mereka. Semakin banyak institusi yang terlibat, maka semakin banyak sumber daya yang dapat dimanfaatkan (Chaskin dkk., 2001; Sulastri, 2012; Warner, 1999; Uphoff, 2000).

\section{Proses pelaksanaan monitoring dan evaluasi}

Pada buku pedoman pengelolaan Kampung KB (BKKBN, 2017: 14, 40-41, dan Lampiran 1 halaman viii) dinyatakan bahwa kegiatan monitoring dan evaluasi di Kampung KB merupakan tugas PKB/PLKB. Kegiatan yang dimonitor dan dievaluasi adalah tugas dari Seksi Reproduksi pada kepengurusan Kampung KB. Aspek-aspek yang dimonitor dan dievaluasi terfokus pada Kegiatan KIE/Penyuluhan KB dan Pelayanan Kontrasepsi (Tabel 4.a).

Kegiatan KIE atau penyuluhan dengan kegiatan pelayanan KB tidak dapat dievaluasi secara tersendiri, tetapi harus merujuk pada jumlah PUS kelompok sasaran. Sebagaimana disarankan oleh PATH UNFPA (2008) bahwa pelayanan KIE atau penyuluhan KB berkualitas memerlukan data kelompok sasaran: berapa jumlahnya; karakteristiknya bagaimana, dan bagi yang tidak sedang menggunakan alat kontrasepsi; apa alasannya. Kelompok sasaran ini terdiri dari PUS unmet need $\mathrm{KB}$ agar menggunakan salah satu alat kontrasepsi, PUS akseptor non-MJP agar menggunakan alat kontrasepsi MJP, dan PUS akseptor MJP agar tetap menggunakan alat kontrasepsi MJP. Dengan demikian selain kedua kegiatan itu, kegiatan pencatatan data PUS dan kegiatan identifikasi PUS sasaran layanan yang seyogyanya juga dimonitor dan dievaluasi. Indikator proses dan indikator output untuk kegiatan KIE/penyuluhan dan pelayanan kontrasepsi pun seyogyanya diselaraskan (Tabel 4.b). Untuk melakukan evaluasi hasil diperlukan pemutakhiran data kelompok sasaran untuk melacak status kesertaan ber-KB mereka, sehingga indikator output dapat diidentifikasi.

Petugas lapangan yang bertugas melakukan monitoring dan evaluasi adalah PKB/PLKB terhadap kegiatan KB yang seyogyanya dilakukan oleh Seksi Reproduksi. Seksi Reproduksi di kedua Kampung KB ini belum terlibat dalam kegiatan operasional KB. Selain itu, PKB/PLKB di Kampung KB RW 04 Desa Mulyasari mulai bertugas pada bulan Oktober 2018, oleh karena itu kegiatan monitoring dan evaluasi oleh PKB/PLKB di Kampung KB ini tidak dapat diidentifikasi. Di Kampung KB RW 05 Desa Kertasari terdapat PKB/PLKB tetapi jika didudukkan dalam perannya sebagai Petugas Monitoring dan Evaluasi untuk Kegiatan KB yang dilakukan oleh Seksi Reproduksi, ia juga tidak dapat melakukan kegiatan ini karena Seksi Reproduksi belum berperan. 
Tabel 4.a. Pedoman indikator keberhasilan program KB di Kampung KB

\begin{tabular}{|c|c|c|c|c|}
\hline No. & $\begin{array}{l}\text { Tugas Seksi } \\
\text { Reproduksi }\end{array}$ & Indikator Input & Indikator Proses & $\begin{array}{l}\text { Indikator } \\
\text { Output }\end{array}$ \\
\hline \multirow[t]{2}{*}{1.} & $\begin{array}{l}\text { a. Memotivasi PUS } \\
\text { untuk Ber-KB }\end{array}$ & \multirow{3}{*}{$\begin{array}{l}\text { a. Petugas (Kader Posyandu, } \\
\text { Sub PPKBD, PPKBD, } \\
\text { PPL Posyandu, } \\
\text { PKB/PLKB } \\
\text { b. Kegiatan-kegiatan terkait } \\
\text { c. Anggaran Kampung KB } \\
\text { d. Ketersediaan Sarana dan } \\
\text { Prasarana. }\end{array}$} & \multirow{2}{*}{$\begin{array}{l}\text { Frekuensi dan Kualitas } \\
\text { Kegiatan } \\
\text { KIE/Penyuluhan }\end{array}$} & $\begin{array}{l}\text { Jumlah PUS } \\
\text { Tidak ber-KB }\end{array}$ \\
\hline & $\begin{array}{l}\text { b. Membina Kelang- } \\
\text { sungan Ber-KB }\end{array}$ & & & \multirow{2}{*}{$\begin{array}{l}\text { Jumlah Keserta- } \\
\text { an Ber-KB per } \\
\text { Mix Kontrasepsi }\end{array}$} \\
\hline 2. & $\begin{array}{l}\text { Penggerakan } \\
\text { Pelayanan } \\
\text { Kontrasepsi }\end{array}$ & & $\begin{array}{l}\text { Frekuensi } \\
\mathrm{KB}\end{array}$ & \\
\hline
\end{tabular}

Sumber: BKKBN, 2017: 40-41 dan Lampiran 1 halaman viii

Tabel 4.b. Rekomendasi indikator keberhasilan program KB di Kampung KB

\begin{tabular}{|c|c|c|c|c|}
\hline No. & $\begin{array}{l}\text { Tugas Seksi } \\
\text { Reproduksi }\end{array}$ & Indikator Input & Indikator Proses & Indikator Output \\
\hline 1. & $\begin{array}{l}\text { Memantau } \\
\text { Pencatatan } \\
\text { Data }\end{array}$ & \multirow[t]{4}{*}{ 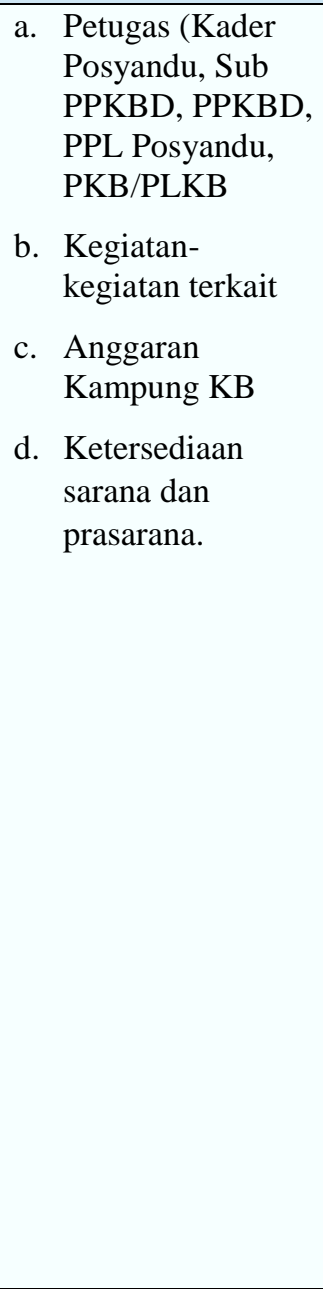 } & $\begin{array}{l}\text { a. Kelengkapan jenis data } \\
\text { yang dikumpulkan } \\
\text { (Instrumen } \\
\text { Pengumpulan data) } \\
\text { b. Kelengkapan cakupan } \\
\text { jumlah PUS yang } \\
\text { tercatat menurut } \\
\text { kesertaan ber-KB } \\
\text { c. Proses identifikasi } \\
\text { sasaran layanan }\end{array}$ & $\begin{array}{l}\text { PUS sasaran layanan } \\
\text { teridentifikasi: } \\
\text { Tersedia Daftar PUS } \\
\text { Sasaran Layanan (Data } \\
\text { Mikro) } \\
\text { a. PUS unmet need KB } \\
\text { b. PUS Akseptor non- } \\
\text { MJP } \\
\text { c. PUS Akseptor MJP } \\
\text { berikut karakteristik } \\
\text { demografisnya (Empat } \\
\text { Terlalu). Bagi PUS unmet } \\
\text { need KB ditambah dengan } \\
\text { alasan tidak ber-KB. }\end{array}$ \\
\hline \multirow[t]{2}{*}{2.} & $\begin{array}{l}\text { a. Memotivasi } \\
\text { PUS untuk } \\
\text { ber-KB }\end{array}$ & & $\begin{array}{ll}\text { a. } & \text { Jumlah/proporsi PUS } \\
\text { unmet need KB } \\
\text { mendapat layanan KIE } \\
\text { b. Kualitas Keg. KIE/Pe- } \\
\text { nyuluhan (misalnya } \\
\text { Enam indikator kualitas } \\
\text { layanan Bruce) }\end{array}$ & $\begin{array}{l}\text { Jumlah/Proporsi } \\
\text { unmet need } \\
\text { (berkurang) }\end{array}$ \\
\hline & $\begin{array}{l}\text { b. Membina } \\
\text { kelangsung- } \\
\text { an ber-KB }\end{array}$ & & $\begin{array}{ll}\text { a. } & \text { Jumlah/proporsi Aksep- } \\
\text { tor MJP mendapat pem- } & \\
\text { binaan (agar tetap meng- } & \text { gunakan alkon MJP). } \\
\text { b. } & \text { Jumlah/proporsi } \\
& \text { Akseptor non-MJP KIE } \\
& \text { alat kontrasepsi MJP } \\
& \text { (agar beralih ke MJP) }\end{array}$ & \multirow[t]{2}{*}{$\begin{array}{l}\text { a. Jumlah/Proporsi } \\
\begin{array}{l}\text { Akseptor MJP } \\
\text { (bertambah) }\end{array} \\
\text { b. Jumlah/Proporsi } \\
\begin{array}{l}\text { Akseptor Non-MJP } \\
\text { (berkurang) }\end{array}\end{array}$} \\
\hline 3. & $\begin{array}{l}\text { Penggerakan } \\
\text { Pelayanan } \\
\text { Kontrasepsi }\end{array}$ & & $\begin{array}{l}\text { Proporsi PUS memerlukan } \\
\text { kontrasepsi yang mendapat } \\
\text { pelayanan. }\end{array}$ & \\
\hline
\end{tabular}

Sumber: Hasil olah data 
Dalam kegiatan KB di Kampung KB, termasuk di dalamnya penanganan unmet need $\mathrm{KB}$, Seksi Reproduksi yang merupakan unsur dari kepengurusan Kampung KB diharapkan banyak berperan. Merujuk pada tugas Seksi Reproduksi yang cukup berat, cukup sulit bagi ketua pengurus Kampung KB mendapatkan orang yang mempunyai kualifikasi untuk menjalankan tugas tersebut. Tidak hanya syarat pengetahuan dan pengalaman di bidang $\mathrm{KB}$, tetapi diperlukan juga komitmen tinggi karena mereka adalah relawan yang tidak mendapat imbalan materi tetapi tuntutan tugasnya demikian berat.

PKB/PLKB di Kampung KB RW 05 Desa Kertasari memiliki data PUS unmet need KB terbaru bulan Oktober 2018 sebanyak tujuh PUS, akan tetapi karena dokumen data mikro sebelumnya tidak tersedia maka tidak dapat diketahui apakah PUS tersebut adalah PUS unmet need $\mathrm{KB}$ baru atau PUS unmet need KB lama yang masih belum tertangani.
Data Kesertaan PUS ber-KB terbaru di Kampung KB RW 04 Desa Mulyasari belum tersedia, sehingga untuk mengetahui kondisi terakhir kesertaan PUS ber-KB, terutama PUS unmet need $\mathrm{KB}$, dilakukan pemutakhiran data dengan menggunakan data PUS hasil pendataan keluarga 2015 revisi sebagai data dasar. Jenis data yang dikumpulkan mencakup data untuk mengidentifikasi PUS unmet need $\mathrm{KB}$, karakteristik demografisnya, dan alasan tidak ber-KB. Daftar PUS tersebut dipilah menurut wilayah RT agar dapat ditelusuri oleh kader Posyandu. Data PUS Bulan Oktober 2018 dimasukkan pada kolom yang bersebelahan dengan data tahun 2015 . Selanjutnya dilakukan identifikasi perubahan status PUS dari tahun 2015 ke tahun 2018. Hasil olah data ini dapat melihat perubahan kesertaan ber-KB PUS per RT. Data tersebut dapat digunakan untuk mengevaluasi capaian hasil pelayanan selama periode 2015-2018 (Tabel 5) dan data mikronya sebagai bekal untuk pelayanan berikutnya.

Tabel 5

Perubahan kesertaan PUS ber-KB di Kampung KB RW 04 Desa Mulyasari

Kecamatan Cilaku Kabupaten Cianjur 2015-2018

\begin{tabular}{|c|c|c|c|c|c|c|c|c|c|c|c|c|c|c|c|c|c|}
\hline \multicolumn{18}{|c|}{ Perubahan PUS PK 2015 pada Bulan Oktober 2018} \\
\hline \multirow{3}{*}{$\begin{array}{c}\text { Keterangan } \\
\text { PUS }\end{array}$} & \multirow{2}{*}{\multicolumn{4}{|c|}{$\begin{array}{c}\text { PUS Pengguna Alat } \\
\text { Kontrasepsi } \\
\text { Alat Kontrasepsi yang } \\
\text { sedang/pernah digunakan }\end{array}$}} & \multicolumn{7}{|c|}{ PUS Tidak Menggunakan Alat Kotrasepsi } & \multirow{2}{*}{\multicolumn{4}{|c|}{ Bukan PUS }} & \multirow{3}{*}{$\begin{array}{l}\text { PUS } \\
\text { Pinda } \\
\text { hDom } \\
\text { i-sili }\end{array}$} & \multirow{3}{*}{$\begin{array}{c}\text { Jumlah } \\
\text { PUS }\end{array}$} \\
\hline & & & & & \multicolumn{2}{|c|}{ IAS } & \multicolumn{3}{|c|}{$\begin{array}{l}\text { Unmet Need KB } \\
\text { IAD dan TIAL }\end{array}$} & \multicolumn{2}{|c|}{ Selibat } & & & & & & \\
\hline & Pil & Suntik & $\begin{array}{c}\text { Im- } \\
\text { plant }\end{array}$ & Mow & Hamil & $\begin{array}{l}\text { Tidak } \\
\text { Hamil }\end{array}$ & Hamil & $\begin{array}{l}\text { Alasan } \\
\text { Agama }\end{array}$ & $\begin{array}{c}\text { Alasan } \\
\text { Lain }\end{array}$ & Nifas & TKI & $\begin{array}{l}\text { Cerai } \\
\text { Hidup }\end{array}$ & $\begin{array}{l}\text { Cerai } \\
\text { Mati }\end{array}$ & $\begin{array}{l}\text { Tdk } \\
\text { Subur }\end{array}$ & $\begin{array}{l}\text { Meno- } \\
\text { pause }\end{array}$ & & \\
\hline $\begin{array}{l}2015 \\
\text { (Akseptor KB) }\end{array}$ & 77 & 139 & 27 & $\mathbf{0}$ & & & & & & & & & & & & & 243 \\
\hline $\begin{array}{l}\text { Peubahan } \\
2018 \\
\end{array}$ & 38 & 118 & 10 & $\mathbf{0}$ & 5 & 9 & 4 & 1 & 0 & 3 & 20 & 4 & 4 & 2 & 11 & 14 & 208 \\
\hline $\begin{array}{l}2015 \text { (Pernah } \\
\text { Ber-KB) }\end{array}$ & 33 & 78 & 10 & $\mathbf{0}$ & 6 & 17 & 1 & 0 & 97 & 0 & 0 & & & & & & 121 \\
\hline $\begin{array}{l}\text { Perubahan } \\
2018 \\
\end{array}$ & 11 & 34 & 1 & 0 & 1 & 6 & 2 & 4 & 0 & 0 & 14 & 9 & 6 & 1 & 28 & 4 & 73 \\
\hline $\begin{array}{l}2015 \text { (tidak } \\
\text { Pernah KB) }\end{array}$ & & & & & 1 & 6 & 4 & 0 & 51 & 0 & 0 & & & & & & 62 \\
\hline $\begin{array}{l}\text { Perubahan } \\
2018 \\
\end{array}$ & 6 & 10 & 2 & 1 & 0 & 0 & 1 & 4 & 0 & 0 & 1 & 3 & 2 & 11 & 14 & 7 & 25 \\
\hline & & & & & & & & PUS 201 & & & & & & & & & \\
\hline $\begin{array}{l}\text { PUS PK } 2015 \\
\text { Pada Thn } \\
2018 \\
\end{array}$ & 55 & 162 & 13 & 1 & 6 & 15 & 7 & 9 & 0 & 3 & 35 & 16 & 12 & 14 & 53 & 25 & 306 \\
\hline $\begin{array}{l}\text { PUS Baru } \\
2018\end{array}$ & 8 & 41 & 2 & 0 & 4 & 8 & 2 & 1 & 0 & 0 & 28 & & & & & & 93 \\
\hline $\begin{array}{l}\text { Jumlah PUS } \\
\text { Oktober }\end{array}$ & 63 & 203 & 15 & 1 & 10 & 23 & 9 & 10 & 0 & 3 & 63 & & & & & & 400 \\
\hline
\end{tabular}

Sumber: Hasil olah data 
Data pada Tabel 5 tersebut menunjukkan bahwa 65 dari 183 PUS tidak menggunakan alat kontrasepsi berubah statusnya menjadi akseptor KB; tetapi terdapat 19 PUS yang semula akseptor $\mathrm{KB}$ berubah menjadi bukan akseptor KB. 65 akseptor KB ini (61 diantaranya berasal dari PUS unmet need $\mathrm{KB}$ ) dapat diklaim sebagai keberhasilan pelayanan dalam tiga tahun terakhir. Proporsi unmet need KB 2015 sebesar 38,67\% (153 dari 396 PUS memerlukan alat kontrasepsi) menurun drastis pada tahun 2018 menjadi 6,48\% (16 dari 247 PUS yang memerlukan alat kontrasepsi). Proporsi unmet need KB ini bahkan jauh lebih kecil dari target nasional tahun 2018 sebesar 10,14\%. Keberhasilan penurunan proporsi ini merupakan konsekuensi semakin mudahnya calon akseptor mendapatkan pelayanan kontrasepsi serta kontribusi pelayanan KIE/Konseling KB oleh berbagai pihak, termasuk di dalamnya kader Posyandu, bidan Desa, PPL Posyandu, pembinaan dari koordinator wilayah Kecamatan Cilaku, disertai fasilitas pelayanan KB Pemerintah yang relatif sering dilakukan.

Perlu diperhatikan bahwa berkurangnya jumlah PUS dari 426 menjadi 306, karena terdapat 92 PUS hilang permanen, karena pindah domisili, menopause dan tidak subur; dan terdapat pula 28 PUS hilang sementara karena cerai hidup dan cerai mati (salah satu pasangan meninggal dunia). 35 PUS yang salah satu pasangannya menjadi TKI, dalam jangka waktu tertentu dapat diabaikan sementara; tetapi 55 PUS yang sedang tidak menggunakan alat kontrasepsi, 19 diantaranya umnet need $\mathrm{KB}$, memerlukan perhatian dari tenaga pelayanan KIE/Konseling KB. Peserta KB Aktif MJP 5,67\% dan yang Non MJP 94,33\% juga masih memerlukan pembinaan.

Cara pemutakhiran data ini merupakan salah satu contoh yang dapat digunakan untuk kepentingan evaluasi hasil (summative evaluation); untuk mengidentifikasi indikator output dari penanganan PUS unmet need $\mathrm{KB}$ maupun pembinaan PUS yang sebelumnya sudah menjadi akseptor KB.

\section{KESIMPULAN}

Kajian ini menemukan berbagai isu yang muncul dalam proses penanganan unmet need $\mathrm{KB}$ pada kedua Kampung KB yang menjadi studi kasus dalam penelitian ini. Berbagai faktor yang memengaruhi proses penanganan ini meliputi ketersediaan instrumen pengumpulan dan pencatatan data terkait, serta perencanaan KIE/konseling KB. Proses monitoring dan evalusi juga perlu mendapat perhatian penting, termasuk di dalamnya proses pemutakhiran data, sebagai tolak ukur output keberhasilan penanganan PUS unmet need KB.

Terhambatnya layanan pada PUS dengan unmet need $\mathrm{KB}$ juga turut dipengaruhi oleh tumpang tindihnya beban kerja para petugas terkait. Belum adanya penyelarasan tugas pada instansi di level berbeda berakibat pada terganggunya relasi kerja antar institusi yang terlibat dalam proses penanganan unmet need $\mathrm{KB}$ ini. Berbagai temuan dalam kajian ini diharapkan dapat memberikan gambaran mengenai pentingnya efisiensi dan efektivitas antar kelembagaan terkait. Selain itu, perlu kejelasan tugas dan pengaturan tata kerja antar instansi-instansi terkait seperti Dinas PPKBP3A di tingkat kabupaten dan BKKBN di tingkat pusat, juga institusi yang berhubungan langsung dengan masyarakat (kader dan PPL Posyandu, sub PPKBD, ketua RT, ketua RW, pengurus Kampung KB, PKB/PLKB, PPKBD, bidan desa, dan Pustu). Koordinasi tersebut diperlukan dalam seluruh tahapan penanganan unmet need $\mathrm{KB}$.

Hal lain yang perlu menjadi perhatian penting merujuk pada kondisi layanan di Kampung KB adalah perencanaan KIE/Konseling $\mathrm{KB}$ dalam penanganan PUS unmet need $\mathrm{KB}$ yang belum mengacu pada karakteristik PUS sasaran layanan. Padahal, karakteristik PUS sasaran layanan penting menjadi rujukan agar pelayanan KIE/Konseling KB lebih terfokus pada kebutuhan PUS. Dalam KIE/Konseling $\mathrm{KB}$, cakupan informasi, kejelasan dalam pemberian informasi, termasuk efek yang dapat ditimbulkan dari alat kontrasepsi tertentu dan cara menanganinya diperlukan oleh kelompok sasaran untuk membantu mereka membuat keputusan dalam pemilihan alat kontrasepsi.

Hasil kajian menunjukkan bahwa kedua Kampung KB beranjak dari beban masalah tingkat unmet need $\mathrm{KB}$ yang berbeda. Walaupun pada keduanya Seksi Reproduksi belum berperan, petugas lini lapangan di Kampung KB RW 04 Desa Mulyasari yang mempunyai beban lebih berat mampu mengajak 61 PUS yang tercatat pada tahun 2015 sebagai PUS unmet need $\mathrm{KB}$ menjadi pengguna salah satu alat kontrasepsi. 
Sementara itu, proporsi unmet need KB di Kampung KB RW 04 Desa Mulyasari berubah dari 38,67\% pada tahun 2015 (data PK 2015 revisi) menjadi 6,48\% pada tahun 2018; sementara di Kampung KB RW 05 Desa Kertasari berubah dari 9,03\% pada tahun 2015 menjadi $5,46 \%$ pada tahun 2018. Meskipun begitu, peningkatan layanan pada PUS unmet need KB masih tetap diperlukan. Peningkatan layanan utamanya difokuskan pada perapian instrumen pengumpulan data PUS yang harus diisi oleh kader Posyandu dan PPKBD. Selama ini, instrumen yang mereka gunakan dianggap cukup merepotkan karena terdiri dari berbagai format dan kelengkapan data yang berbeda. Agar lebih efisien, formulir pencatatan data untuk pelayanan KB sebaiknya satu jenis saja. Format instrumen pengumpulan data tersebut juga perlu diselaraskan dengan kebutuhan penyediaan data mikro PUS unmet need KB untuk kebutuhan layanan dan kebutuhan penyediaan data makro untuk kepentingan evaluasi program layanan.

\section{DAFTAR PUSTAKA}

Ali, A., \& Okud, A. (2013). Factors affecting unmet need for family planning in Eastern Sudan. BMC Public Health, 13(102), 1-5. https://doi.org/ 10.1186/1471-2458-13-102

BKKBN. (2016). Rencana strategis Badan Kependudukan dan Keluarga Berencana Nasional tahun 2015-2019 (REVISI). BKKBN.

. (2017). Pedoman pengelolaan Kampung KB: Pedoman bagi pengelola Kampung KB di lini lapangan. BKKBN.

BPS, BKKBN, \& Macro Inc. (2017). Laporan pendahuluan survei demografi dan kesehatan Indonesia 2017. BPS, BKKBN, \& Macro Inc.

Bradley, S. E. K., Croft, T. N., Fishel, J. D., \& Westoff, C. F. (2012). Revising unmet need for family planning. ICF International. https://dhsprogram. com/pubs/pdf/AS25/AS25\%5B12June2012\%5D .pdf

Bruce, J. (1990). Fundamental elements of the quality of care: A simple framework. Studies in Family Planning, 21(2), 61-91. https://doi.org/ $10.2307 / 1966669$

Chaskin, R.J., Brown, P., Venlzatesh, S., \& Vidal, A. (2001). Building community capacity. Aldine de Gruyer.

Dinas PPKBP3A Kabupaten Cianjur. (2017). Rencana strategis DPPKBP3A Kabupaten Cianjur 20172021. DPPKBP3A Kabupaten Cianjur.
Hameed, W., Azmat, S. K., Bilgrami, M., \& Ishaqe, M. (2011). Determining the factors associated with "unmet need for family planning": A crosssectional survey in 49 districts of Pakistan. Pakistan Journal of Public Health, 1(1). 21-27. https://www.pjph.org/index.php/pjph/issue/view /27/Vol1No1

Humas BKKBN. (2019). Komitmen BKKBN dalam ICPD25: Mengakhiri kebutuhan KB yang tidak terpenuhi (unmet need). BKKBN.

Jain, A.K., Obare, F., RamaRao, S. \& Askew, I. (2013). Reducing unmet need by supporting women with met need. International Perspectives on Sexual and Reproductive Health, 39(3), 133-141. www.jstor.org/stable/23596124

Machiyama, K., Casterline, J. B., Mumah, J. N., Huda, F. A., Obare, F., Odwe, G., Kabiru, C. W., Yeasmin, S., \& Cleland, J. (2017). Reasons for unmet need for family planning, with attention to the measurement of fertility preferences: Protocol for a multi-site cohort study. Reproductive Health, 14(23), 1-11. https://doi.org/10.1186/s12978-016-0268-z

Pal, A, Mohan, U., Idris, M. Z., \& Masood, J. (2014). Factors affecting unmet need for family planning in married women of reproductive age group in urban slums of Lucknow. Indian Journal Of Community Health, 26(1), 44-49. https://www.iapsmupuk.org/journal/index.php/IJ $\mathrm{CH} /$ article/view/372

PATH UNFPA. (2008). Reducing unmet need for family planning: Evidence-based strategies and approaches. Program for Appropriate Technology in Health (PATH). https://www.unfpa.org/sites/default/files/resourc e-pdf/EOL_nov08.pdf

Peraturan Menteri Pendayagunaan Aparatur Negara dan Reformasi Birokrasi Republik Indonesia Nomor 21 Tahun 2018 tentang Jabatan Fungsional Penyuluh Keluarga Berencana.

Puslitbang KB dan KS BKKBN. (2017). Laporan survei kinerja dan akuntabilitas program. BKKBN.

Sulastri, S. (2012). Pengembangan kapital sosial komunitas desa (Studi kasus pada komunitas Desa Siaga Nagarawangi Kecamatan Rancakalong Kabupaten Sumedang). Indonesian Journal of Dialectics, 2(3). http://jurnal.unpad.ac.id/ijad/article/view/2719 
Penanganan Unmet Need KB di Kampung KB ...|Sri Sulastri dkk.

Uphoff, N. (2000). Understanding social capital: Learning from the analysis and experience of participation. Dalam P. Dasgupta \& I. Serageldin (Ed.), Social capital: A multifaceted perspective (hal. 215-249). The World Bank.

Warner, M. (1999). Social capital construction and the role of local state. Rural Sociology, 64(3), 373393. https://doi.org/10.1111/j.1549-0831.1999. tb00358.x
Warung Bidan. (2016). 4 terlalu dalam kehamilan (Terlalu muda, tua, dekat, banyak). http://warungbidan.blogspot.com/2016/03/4terlalu-dalam-kehamilan-terlalu-muda.html

Yin, R.K. (2003). Case Study Research. Sage Publications 
Jurnal Kependudukan Indonesia | Vol. 14, No. 2, Desember 2019 | 119-136 